\title{
CURIR 99-4085 \\ Evaluation of Possible Human-Induced Effects on Ground-Water Quality, St. Charles Mesa, Colorado, 1997
}

\section{INTRODUCTION}

St. Charles Mesa (Mesa) is an upland terrace southeast of Pueblo that has an area of about 10 square miles (fig. 1). The Mesa has been irrigated for agricultural purposes since the late 1800's (Dumeyer, 1975). The unconfined sand and gravel aquifer, originally deposited by
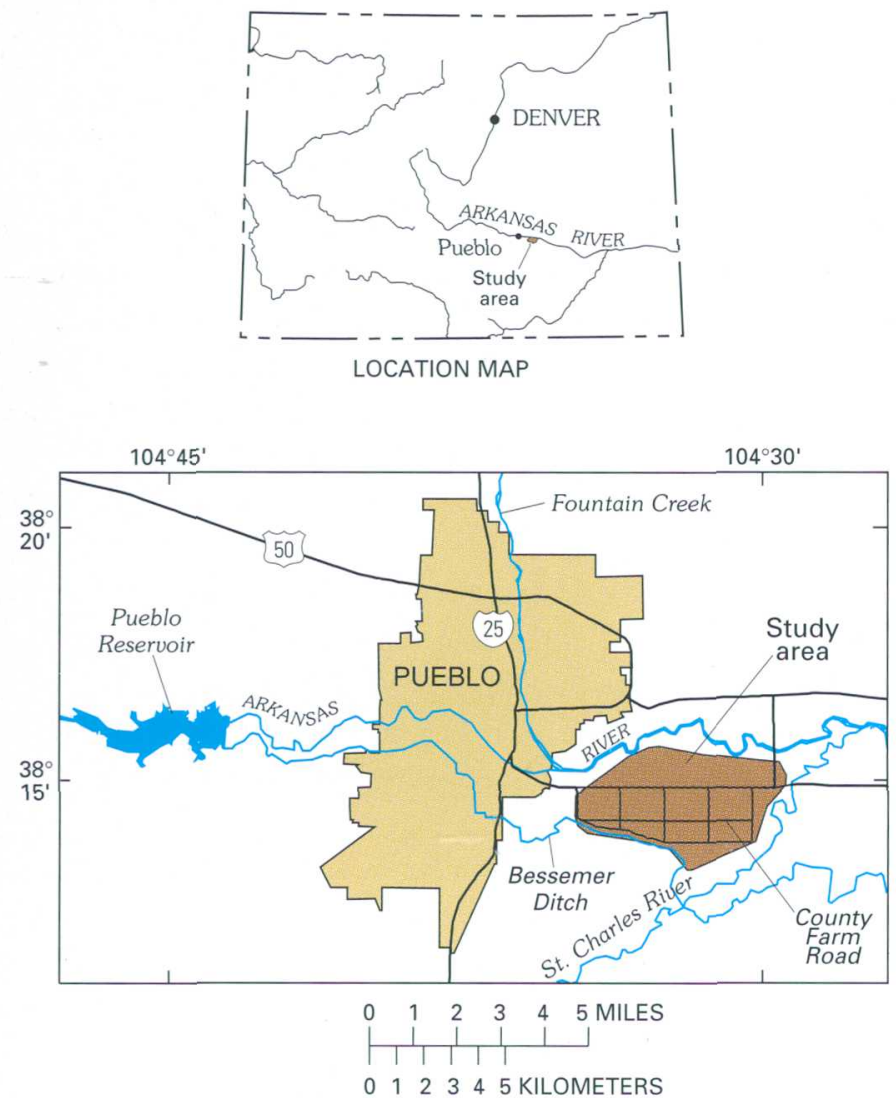

Figure 1. Location of study area. the Arkansas River, overlies an eroded shale-bedrock surface (Scott, 1969). Ground-water flow is generally from the southwest to the northeast, with the highest water-table elevations in the vicinity of Bessemer Ditch near County Farm Road [Dumeyer, 1975; U.S. Geological Survey (USGS) Ground-Water Site Inventory data base].

During the last 25 years, the Mesa has become increasingly urbanized as cultivated fields have been converted to residential areas. However, much of the Mesa is still dedicated to agriculture and animal husbandry, both of which are potential sources of contaminants to the ground water. Septic systems are another potential source of contaminants to the ground water; all wastewater treatment on the Mesa is provided by septic systems. Because there has been a high water table on much of the Mesa, with ground-water levels within 10 feet of the land surface, the potential exists for septic-system flooding. As the vertical distance between the water table and a septicsystem's leach field decreases, the treatment efficiency of the septic system can be decreased due to thinning of the unsaturated zone below the leach field (fig. 2). The extent of the high water table on the Mesa is described by Brendle (1999).

The U.S. Geological Survey, in cooperation with Pueblo County, collected ground-water samples on the Mesa during July and August 1997 to evaluate whether ground-water quality has been affected by the byproducts of human activities, including septic-system effluent. Samples were obtained from 24 domestic and irrigation wells and 1 spring. The samples were analyzed for chemical constituents and bacteria that can be indicative of the byproducts of human activities: nitrate, ammonia, dissolved organic carbon (DOC), methylene blue active substances (MBAS) (detergents and other natural and synthetic substances), total coliform and Escherichia coli (E. coli) bacteria, and caffeine. 


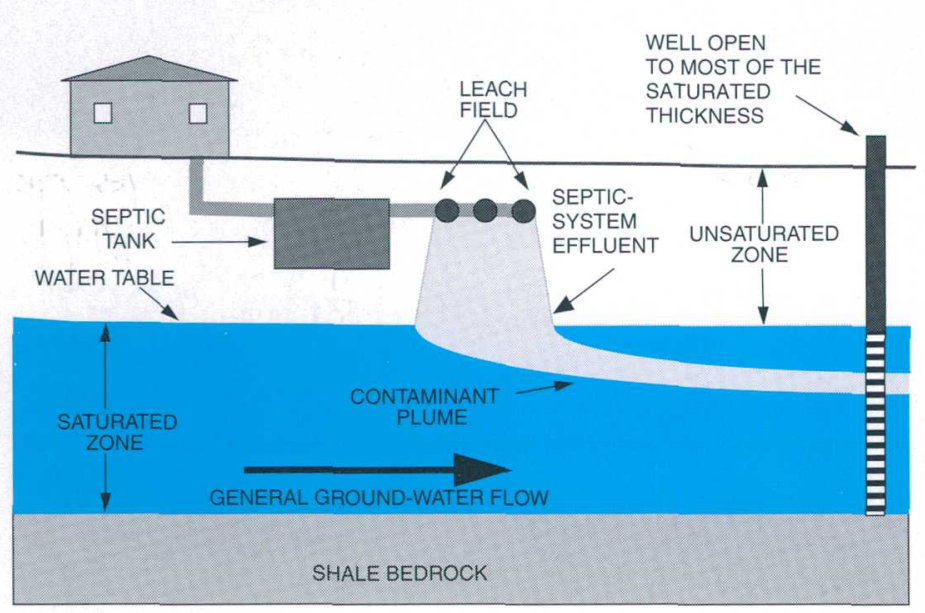

Figure 2. Diagram of a septic-system installation, the general direction of ground-water flow, and the configuration of a plume of ground water that has been degraded by septic-system effluent.

\section{POTENTIAL SOURCES OF CONTAMINANTS TO THE GROUND WATER}

Human-related activities that could potentially contribute contaminants to the ground water include agriculture, animal husbandry, lawn and garden maintenance, and the use of septic systems. Potential sources of contaminants to the ground water on the Mesa include fertilizers applied to lawns, gardens, and farm lands; animal waste from cattle, horses, and other livestock; and septic-system effluent. Water that recharges the ground water and that has been in contact with inorganic fertilizers could be enriched in nitrate or ammonia; water that has been in contact with organic fertilizers could be enriched in nitrate, ammonia, or DOC; and water that has been in contact with animal waste or manure could be enriched in nitrate, ammonia, DOC, and fecal-indicator bacteria. Septic-system effluent could be enriched in nitrate, ammonia, DOC, detergents and other household chemicals, fecal-indicator bacteria, and caffeine. In addition, soils are a potential source of total coliform bacteria.

The evaluation of possible human-induced effects on ground-water quality is the broad focus of this report, but many residents of the Mesa are concerned about the effects of septic-system effluent on ground-water quality. Therefore, a discussion of the geochemical processes affecting septic-system effluent follows to provide residents with an understanding of the processes that occur to decrease the concentrations of contaminants in septic-system effluent.
Although this discussion focuses on chemicals and bacteria in septic-system effluent, the geochemical processes work in similar fashion to decrease the concentrations of potential contaminants originating from animal wastes or lawn, garden, and agricultural chemicals.

\section{REMOVAL OF CHEMICAL AND BIOLOGICAL CONSTITUENTS FROM SEPTIC-SYSTEM EFFLUENT IN THE SUBSOIL}

Several processes occur in the subsoil (unsaturated zone above the water table and the saturated zone below the water table) to decrease the concentrations of chemical and biological constituents in septic-system effluent (fig. 2).

Most of the potential contaminants in septic-system effluent are removed in the unsaturated zone below the leach field and above the water table by oxidation or filtration (Wilhelm, Schiff, and Cherry, 1994). When effluent reaches the unsaturated zone above the water table, it flows through the pores between the particles, such as sand and clays, that make up the subsoil. Large particles and bacteria in the effluent can be filtered by the subsoil, leaving mostly dissolved compounds in the effluent. As the effluent flows through the subsoil, ammonia is oxidized to form nitrate. When nitrate reaches the water table, and if DOC is present and dissolved-oxygen concentrations are low, the nitrate and DOC may be consumed by denitrifying bacteria to produce nitrogen gas. Thus, the concentration of nitrate increases beyond the leach field but then decreases as it travels through the saturated zone (Robertson and others, 1989).

Caffeine and MBAS can be degraded to other compounds by bacteria in the saturated zone in the vicinity of the leach field where the compounds originated, or they can persist in ground water if bacteria are not present or the efficiency of treatment within the saturated zone has been reduced.

Biological constituents in septic-system effluent that can cause disease (pathogenic organisms) include bacteria and viruses. These microorganisms have different survival rates and transport properties in the saturated and unsaturated zones below a leach field. Total coliform and E. coli bacteria can be removed from septic-system effluent by filtration as the effluent flows through the unsaturated zone (Viraraghavan and Warnock, 1976). However, if the water table becomes closer to the land surface, the unsaturated zone thins and more of the bacteria in the effluent can potentially reach the ground water (Canter and Knox, 1985). 


\section{COMPARISON OF MEASURED AND EXPECTED BACKGROUND CONCENTRA- TIONS OF CHEMICAL AND BIOLOGICAL CONSTITUENTS}

The 25 water samples collected in July and August 1997 were analyzed for chemical and bacterial indicators to determine whether Mesa ground water has been affected by the byproducts of human activities, including septic-system effluent. If contaminants from septic-system effluent are reaching the ground water, a long, narrow contaminant plume can be expected to form in the direction of ground-water flow, with little dispersion of the contaminants vertically or horizontally (fig. 2) (Robertson and others, 1989). Thus, because the concentration of chemical and biological constituents may vary with depth in the aquifer and the wells that were sampled are open to most of the saturated thickness of the aquifer (fig. 2), the water samples represent a composite of the ground-water quality in the aquifer.

The ground water of the Mesa is recharged by precipitation and water originating in Pueblo Reservoir, which is delivered to the Mesa and to the St. Charles Mesa Water District through Bessemer Ditch. Chemical analyses of Bessemer Ditch water and precipitation were not available for comparison with ground-water-sample analyses. Data from analyses of water collected from Pueblo Reservoir were assumed to be representative of water reaching the Mesa through the Bessemer Ditch (table 1). Additionally, it was assumed that water that was conveyed from Pueblo Reservoir to the Mesa through Bessemer Ditch did not become enriched in any of the chemical or biological constituents considered in this study.

To determine whether the ground water of the Mesa has been affected by the byproducts of human practices, each chemical or biological constituent was compared to the expected maximum background concentration (concentrations from Pueblo Reservoir) or to the applicable U.S. Environmental Protection Agency (USEPA) maximum contaminant level (MCL) or maximum contaminant level goal (MCLG) (U.S. Environmental Protection Agency, 1995). The MCL and MCLG values are listed in table 1 . If the concentration of a chemical or biological constituent in a sample exceeded the expected maximum background concentration or the USEPA MCL or MCLG, that sample was considered to have been affected by the byproducts of human practices. It was not possible to differentiate the particular practice that may have caused the concentration of a constituent to be higher than the expected background concentration, except for caffeine or
MBAS, both of which are strong indicators that the ground water has been affected by septic-system effluent.

Additionally, an assessment was made to determine whether there was evidence to indicate widespread degradation of the ground water that could be attributed to septicsystem effluent. For this assessment, an approach was used that considered multiple lines of evidence. For a particular sample to be considered affected by septic-system effluent, concentrations of several of the chemical and biological constituents had to be higher than the expected maximum background concentrations or USEPA MCL or MCLG, and there needed to be constituents present, such as caffeine or MBAS, that most likely originated from septic systems. This multiple-lines-of-evidence approach was used because all of the chemical and biological constituents, except caffeine and probably MBAS, can originate from multiple sources.

Concentrations of nitrate in all the wells sampled were below the USEPA maximum contaminant level of 10 milligrams per liter (mg/L) (U.S. Environmental Protection Agency, 1995); concentrations ranged from 0.07 to $9.2 \mathrm{mg} / \mathrm{L}$ (table 2), with a median concentration of $4.2 \mathrm{mg} / \mathrm{L}$. Three of the four samples in which the nitrate concentration was higher than $7 \mathrm{mg} / \mathrm{L}$ were outside the area identified as having a high water table (depth to water less than 10 feet from the land surface) (fig. 3). The observation that 80 percent of the ground-water samples exceeded the expected maximum background concentration for nitrate of less than $1 \mathrm{mg} / \mathrm{L}$ (table 1) indicates that human practices probably have contributed to these concentrations being higher than the expected background concentration.

Ammonia was detected in 18 samples. The range of ammonia concentrations was from $<0.01$ to $0.08 \mathrm{mg} / \mathrm{L}$ (table 2), with a median concentration of $0.03 \mathrm{mg} / \mathrm{L}$. There is no USEPA maximum contaminant level for ammonia. The expected maximum background concentration of ammonia, based on samples obtained from Pueblo Reservoir, was $0.17 \mathrm{mg} / \mathrm{L}$ (table 1 ). All the detections of ammonia were below the expected maximum background concentration. The concentrations of ammonia do not indicate that human practices have contributed ammonia to the ground water.

Dissolved organic carbon was detected in 24 samples, ranging from 0.8 to $9.5 \mathrm{mg} / \mathrm{L}$ (table 2 ), with a median concentration of $1.8 \mathrm{mg} / \mathrm{L}$. There is no USEPA maximum contaminant level for DOC. The concentration of DOC was below the expected maximum background concentration of $3.2 \mathrm{mg} / \mathrm{L}$ in 23 samples (table 1 ). Only one ground-water sample $(9.5 \mathrm{mg} / \mathrm{L})$ exceeded the expected maximum background concentration. The concentrations of DOC in 23 of the samples, which were below the expected maximum 
background concentration, indicate that human practices generally have not contributed significantly to DOC in the ground water.

MBAS were detected in 18 samples. MBAS concentrations ranged from $<0.05$ to $0.15 \mathrm{mg} / \mathrm{L}$ (table 2 ), with a median concentration of $0.05 \mathrm{mg} / \mathrm{L}$. There is no USEPA maximum contaminant level for MBAS. All wells in which MBAS were detected were in the eastern part of the Mesa, from just west of 23rd Lane to east of Baxter Road, and from just south of South Road to the northern part of the study area (fig. 4). The expected maximum background concentration for MBAS was set at $0.05 \mathrm{mg} / \mathrm{L}$, the detection limit of the method of analysis (table 1). The test for MBAS is not definitive for detergents because the test

Table 1. Chemical and bacterial indicators, expected maximum background concentration, and range of concentrations of the indicators in Mesa water samples

i

[USEPA, U.S. Environmental Protection Agency; <, less than; >, greater than; mg/L, milligrams per liter; $\mu \mathrm{g} / \mathrm{L}$, micrograms per liter; MCL, USEPA maximum contaminant level; MCLG, USEPA maximum contaminant level goal; --, constituent has no USEPA drinking-water MCL or MCLG; DOC, dissolved organic carbon; TOC, total organic carbon; \%, percent; POC, particulate organic carbon; mL, milliliters; MBAS; methylene blue active substances; E. coli, Escherichia coli bacteria]

\begin{tabular}{|c|c|c|c|c|c|c|}
\hline \multirow[t]{2}{*}{$\begin{array}{l}\text { Chemical } \\
\text { or bacterial } \\
\text { indicators }\end{array}$} & \multirow[t]{2}{*}{$\begin{array}{l}\text { Expected } \\
\text { maximum } \\
\text { back- } \\
\text { ground } \\
\text { concen- } \\
\text { tration }\end{array}$} & \multirow[t]{2}{*}{$\begin{array}{l}\text { USEPA } \\
\text { drinking- } \\
\text { water MCL } \\
\text { or MCLG }\end{array}$} & \multirow{2}{*}{$\begin{array}{l}\text { Range of } \\
\text { concentrations } \\
\text { in Mesa water } \\
\text { samples }\end{array}$} & \multicolumn{2}{|c|}{$\begin{array}{l}\text { Samples } \\
\text { exceeding } \\
\text { maximum back- } \\
\text { ground concen- } \\
\text { tration }\end{array}$} & \multirow[t]{2}{*}{ Notes } \\
\hline & & & & Number & Percent & \\
\hline $\begin{array}{l}\text { Nitrate plus } \\
\text { nitrite, as } \\
\text { nitrogen }\end{array}$ & . & $\begin{array}{l}10 \mathrm{mg} / \mathrm{L} \\
(\mathrm{MCL}) .\end{array}$ & $0.07-9.2 \mathrm{mg} / \mathrm{L}$ & 20 & 80 & $\begin{array}{l}\text { Expected maximum background concentration based } \\
\text { on concentration of nitrate plus nitrite, as nitrogen, } \\
\text { for Pueblo Reservoir, from which Bessemer Ditch } \\
\text { water originates (Edelmann and others, 1991). }\end{array}$ \\
\hline Ammonia. & $\ldots$ & -- & $<0.01-0.08 \mathrm{mg} / \mathrm{L}$ & 0 & 0. & $\begin{array}{l}\text { Expected maximum background concentration based } \\
\text { on assumption that total ammonia is approximately } \\
\text { equal to dissolved ammonia and the maximum } \\
\text { concentration for total ammonia for Pueblo Reser- } \\
\text { voir, from which Bessemer Ditch water originates } \\
\text { (Edelmann and others, 1991). }\end{array}$ \\
\hline DOC & $3.2 \mathrm{mg} / \mathrm{L}$ & -- & $0.8-9.5 \mathrm{mg} / \mathrm{L}$ & 1 & 4 & $\begin{array}{l}\text { Expected maximum background concentration based } \\
\text { on maximum observed TOC values (approximately } \\
\text { 10\% POC, 90\% DOC, (Thurman, 1986) for Pueblo } \\
\text { Reservoir, from which Bessemer Ditch water origi- } \\
\text { nates (Edelmann and others, 1991). }\end{array}$ \\
\hline MBAS & $\therefore$ & . - & $<0.05-0.15 \mathrm{mg} / \mathrm{L}$ & 18 & 72 & $\begin{array}{l}\text { Methylene blue active substances are detergents and } \\
\text { natural and synthetic chemical compounds. } \\
\text { Expected maximum background concentration is } \\
0.05 \mathrm{mg} / \mathrm{L} \text {, which is the detection limit of the } \\
\text { method. Therefore, a detection of MBAS is consid- } \\
\text { ered as an exceedance of the expected maximum } \\
\text { background concentration. }\end{array}$ \\
\hline $\begin{array}{l}\text { Total } \\
\text { coliform }\end{array}$ & $\begin{array}{l}0 \text { colonies } \\
\text { per } \\
100 \mathrm{~mL}\end{array}$ & $\begin{array}{l}0 \text { colonies } \\
\text { per } 100 \mathrm{~mL} \\
(\mathrm{MCLG})\end{array}$ & $\begin{array}{l}<1 \rightarrow 2,700 \\
\text { colonies } \\
\text { per } 100 \mathrm{~mL}\end{array}$ & 15 & 60 & $\begin{array}{l}\text { Expected maximum background concentrations of total } \\
\text { coliform and } E \text {. coli bacteria are based on USEPA } \\
\text { MCLG for those biological indicators. A detection }\end{array}$ \\
\hline E. coli & $\begin{array}{l}0 \text { colonies } \\
\text { per } \\
100 \mathrm{~mL}\end{array}$ & $\begin{array}{l}0 \text { colonies } \\
\text { per } 100 \mathrm{~mL} \\
(\mathrm{MCLG})\end{array}$ & $\begin{array}{c}<1-9 \text { colonies } \\
\text { per } 100 \mathrm{~mL}\end{array}$ & 2 & 8 & $\begin{array}{l}\text { of } E \text {. coli bacteria indicates some form of fecal } \\
\text { contamination, whether from animal or human } \\
\text { sources. }\end{array}$ \\
\hline Caffeine & $\begin{array}{l}0.04 \mu \mathrm{g} / \mathrm{L} \\
\therefore\end{array}$ & $-\overline{-}$ & $<0.04-0.28 \mu \mathrm{g} / \bar{L}$ & 1 & 6 & $\begin{array}{l}\text { Caffeine does not occur naturally in Colorado ground } \\
\text { or surface waters. Expected maximum background } \\
\text { concentration is } 0.04 \mu \mathrm{g} / \mathrm{L} \text {, which is the detection } \\
\text { limit of the laboratory method. Therefore, a detec- } \\
\text { tion of caffeine is considered as an exceedance of the } \\
\text { expected maximum background concentration. }\end{array}$ \\
\hline
\end{tabular}


Table 2. Chemical and bacterial data for ground-water samples from St. Charles Mesa

[mg/L, milligrams per liter; DOC, dissolved organic carbon; $\mu \mathrm{g} / \mathrm{L}$, micrograms per liter; MBAS, methylene blue active substances; $\mathrm{mL}$, milliliter; $E$. coli, Escherichia coli bacteria; <, less than; >, greater than; --, sample not analyzed for this constituent]

\begin{tabular}{|c|c|c|c|c|c|c|c|c|}
\hline $\begin{array}{c}\text { Map } \\
\text { number } \\
\text { (figs. 3, 4, } \\
\text { and 5) }\end{array}$ & Local identifier & $\begin{array}{l}\text { Nitrate, } \\
\text { as } \\
\text { nitrogen } \\
(\mathrm{mg} / \mathrm{L})\end{array}$ & $\begin{array}{c}\text { Ammonia, } \\
\text { as } \\
\text { nitrogen } \\
(\mathrm{mg} / \mathrm{L})\end{array}$ & $\begin{array}{c}\mathrm{DOC} \\
(\mathrm{mg} / \mathrm{L})\end{array}$ & $\begin{array}{c}\text { Caffeine } \\
(\mu g / L)\end{array}$ & $\begin{array}{l}\text { MBAS } \\
\text { (mg/L) }\end{array}$ & $\begin{array}{c}\text { Total } \\
\text { coliform } \\
\text { (colonies } \\
\text { per } \\
100 \mathrm{~mL} \text { ) }\end{array}$ & $\begin{array}{c}\text { E. coli } \\
\text { (colonies } \\
\text { per } \\
100 \mathrm{~mL} \text { ) }\end{array}$ \\
\hline 1 & SC02106407DACC1 & 0.2 & $<0.01$ & $0 . \overline{8}$ & -- & $<0.05$ & $<1$ & $<1$ \\
\hline 2 & SC02106405DAAC1 & 2.0 & .02 & 1.9 & -- & $<.05$ & 31 & $<1$ \\
\hline 3 & SC02106409BAAD1 & 5.7 & $<.01$ & 1.4 & $<0.04$ & $<.05$ & $>82$ & $<1$ \\
\hline 4 & SC02106409CB1 & 2 & .04 & 1.6 & -- & $<.05$ & $>2,700$ & $<3$ \\
\hline 5 & SC02106409DBAA1 & .9 & $<.01$ & .9 & -- & $<.05$ & $<1$ & $<1$ \\
\hline 6 & SC02106410BBCB1 & 3.7 & .04 & 2.2 & -- & .10 & 9 & $<3$ \\
\hline 7 & SC02106404DDBB1 & 3.1 & .03 & 2.5 & .28 & $<.05$ & 10 & $<3$ \\
\hline 8 & SC02106404DABB1 & 5.2 & .04 & 1.8 & $<.04$ & .05 & $<1$ & $<1$ \\
\hline 9 & SC02106404AABD1 & 5.2 & .04 & 2.0 & $<.04$ & .1 & 130 & 2 \\
\hline 10 & SC02106403CBAB1 & 2.3 & .06 & 1.9 & -- & .05 & $<3$ & $<3$ \\
\hline$\dot{11}$ & $\mathrm{SC} 02106403 \mathrm{BABC} 1$ & 3.2 & .04 & 1.9 & $<.04$ & .05 & 12 & $<3$ \\
\hline 12 & Spring & 3.7 & .04 & 2.8 & $<.04$ & .1 & 7 & $<10$ \\
\hline 13 & $\mathrm{SC} 02106403 \mathrm{ABCC} 1$ & 5.9 & .05 & 2.3 & $<.04$ & .1 & 55 & $<3$ \\
\hline 14 & SC02106402CBBB 1 & 5.3 & $<.01$ & 2.2 & $<.04$ & .05 & $<1^{\prime}$ & $<1$ \\
\hline 15 & SC02106403DBCD1 & .07 & .08 & 9.5 & $<.04$ & .15 & $<3$ & $<3$ \\
\hline 16 & SC02106403DDCC1 & 7.1 & $<.01$ & 1.6 & $<.04$ & .1 & $<1$ & $<1$ \\
\hline 17 & SC02106411BCBB1 & 8.3 & $<.01$ & 2.0 & $<.04$ & .15 & 50 & 9 \\
\hline 18 & SC02106410DBCD1 & 4.3 & .03 & 1.3 & -- & .1 & 23 & $<3$ \\
\hline 19 & SC02106414BCCB1 & .4 & .05 & 1.8 & $<.04$ & $<.05$ & 470 & $<3$ \\
\hline 20 & SC02106414AAAB1 & 7.7 & .04 & -- & $<.04$ & .15 & 120 & $<10$ \\
\hline 21 & SC02106402DCDC1 & 5.9 & $<.01$ & 2.0 & $<.04$ & .1 & $<1$ & $<1$ \\
\hline 22 & SC02106402DBCB1 & 2.7 & .02 & 1.3 & $<.04$ & .05 & $<3$ & $<3$ \\
\hline 23 & SC02106401BCCC1 & 9.2 & .02 & 1.8 & $<.04$ & .15 & $<3$ & $<3$ \\
\hline 24 & SC02106412ACBC 1 & 4.2 & .02 & 1.6 & -- & .05 & 100 & $<3$ \\
\hline 25 & SC02106306BCD1 & 4.7 & .02 & 1.7 & $<.04$ & .1 & 300 & $<3$ \\
\hline
\end{tabular}

indicates a positive result when detergents and other natural and synthetic substances are present in the sample (Greenberg ănd others, 1985). Therefore, the fact that 18 samples were positive for MBAS indicates that human practices may have contributed to MBAS in the ground water, but the source, whether septicsystem effluent or natural or synthetic chemical compounds, cannot be identified.

Total coliform bacteria were detected in 15 samples, and $E$. coli bacteria were detected in 2 samples (fig. 5) (table 2). The USEPA rule for total : coliform bacteria in public drinking-water supplies (U.S. Environmental Protection Agency, 1995) (table 1) does not apply directly to the private wells that were sampled for this study. Nonetheless, the rule can be generally used as a guideline for determining the suitability of the water from these wells for human consumption. The concentrations of total coliforms in the ground water exceeded the USEPA maximum contaminant level goal for bacteria in drinking water of zero colonies per 100 milliliters. Eleven samples in which bacteria were detected were obtained from wells in areas of the Mesa where the water table is more than 10 feet below land surface (fig. 5), whereas four samples containing bacteria were in areas where the water table is within 10 feet of land surface. The 


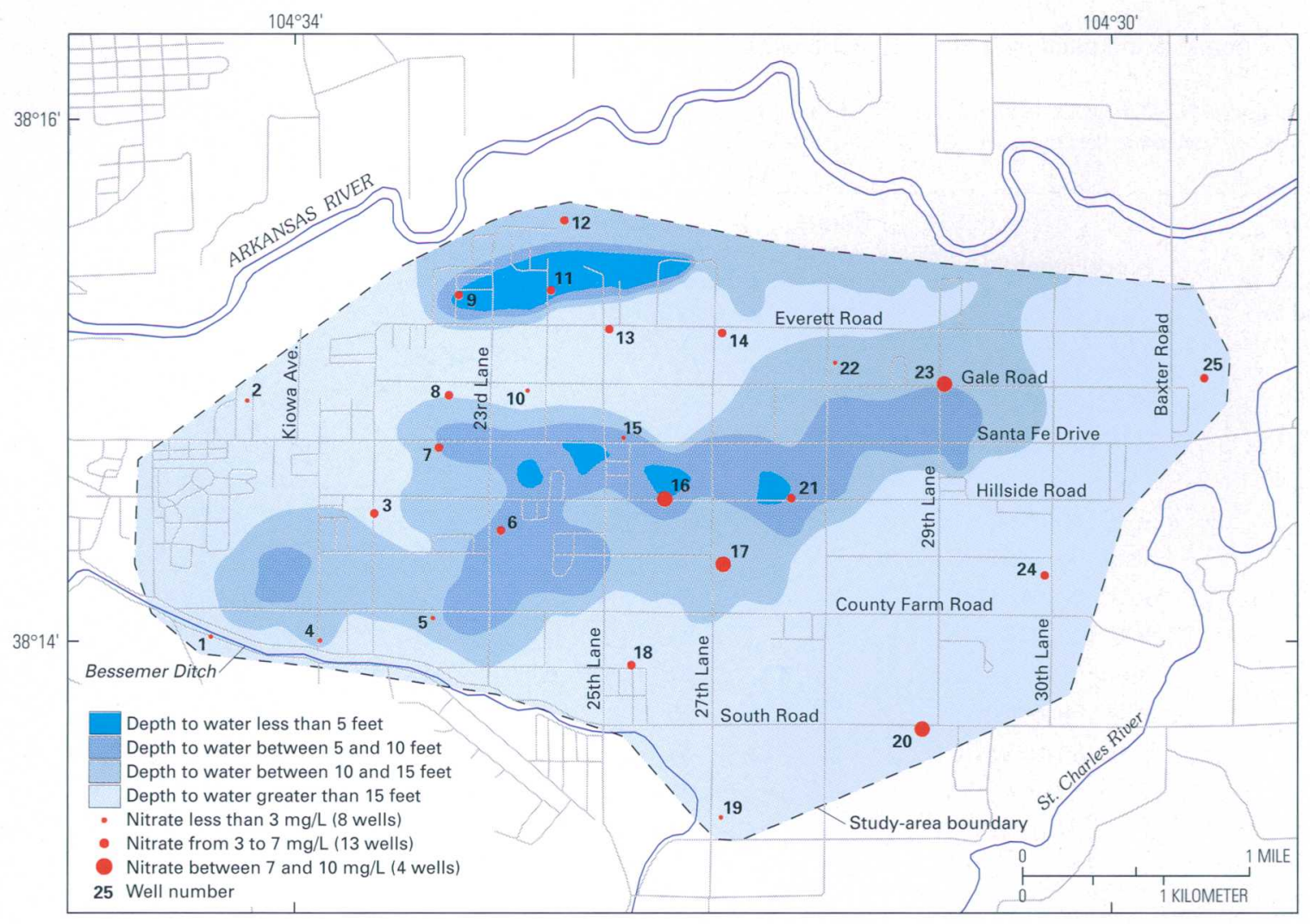

Figure 3. Nitrate concentrations in wells sampled on St. Charles Mesa during July and August 1997.

presence of bacteria in the ground water may be due in part to the coarseness of the subsoil material and the rate at which recharging water containing bacteria, whether precipitation, canal diversions, or septic-system effluent, can flow to the water table. The detections of total coliform bacteria do not necessarily indicate that septicsystem effluent has degraded ground-water quality because total coliform bacteria can originate from animal fecal matter and soil organisms. The detections of E. coli in two wells indicate degradation of the ground water by fecal matter at those locations, but whether the source was septic-system effluent or animal waste cannot be differentiated in these samples.

Caffeine was detected in one sample, which contained 0.28 microgram per liter $(\mu \mathrm{g} / \mathrm{L})$ (table 2$)$. There is no USEPA maximum contaminant level for caffeine. The expected maximum background concentration for caffeine was set at $0.04 \mu \mathrm{g} / \mathrm{L}$, the detection limit of the method of analysis (table 1). The presence of caffeine in the sample from well 7 may indicate septic-system contamination of ground water in the vicinity of the well because septic-system effluent is the only source of caffeine to the ground water. However, the single detection of caffeine indicates that either caffeine is not generally present in the ground water or, if caffeine is present, concentrations are decreased through chemical or biological processes. Therefore, the caffeine data do not indicate widespread degradation of the ground water by septicsystem effluent.

When the concentrations of all the constituents for each well are compared using the multiple-lines-ofevidence approach, the data indicate that there is insufficient evidence to indicate a widespread presence of septicsystem effluent in Mesa ground water.

Concentrations of nitrate, MBAS, bacteria, and caffeine in some ground-water samples collected from the Mesa were higher than would be expected for ground water that was not affected by the byproducts of human practices. Detections of MBAS and caffeine indicate that septic-system effluent may be present in the ground water on the Mesa. Evidence indicates that degradation of ground water on the Mesa that could be associated with septic-system effluent is not widespread, but human practices have affected the quality of Mesa ground water. 


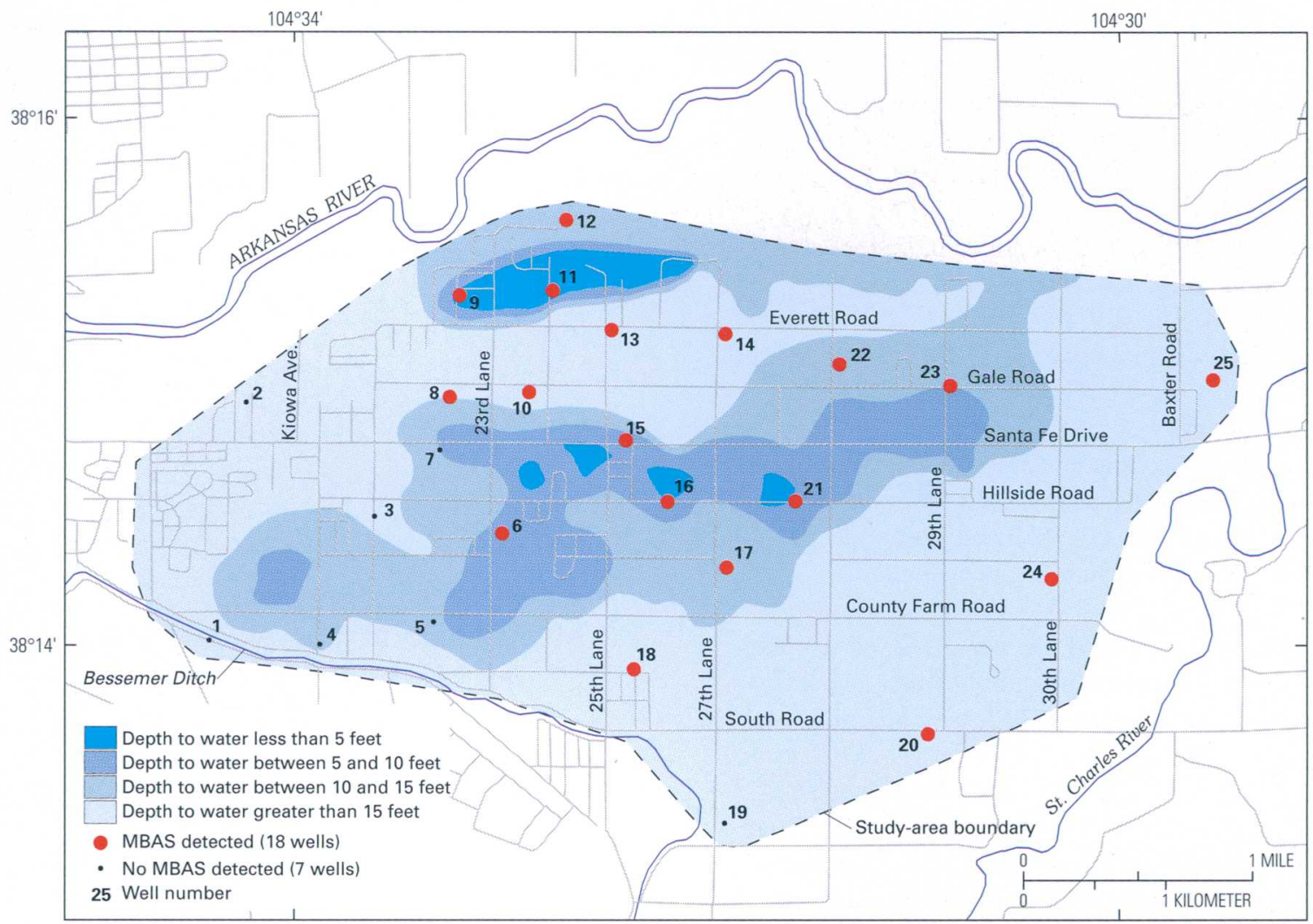

Figure 4. Detections of methylene blue active substances (MBAS) in samples obtained from wells on St. Charles Mesa during July and August 1997

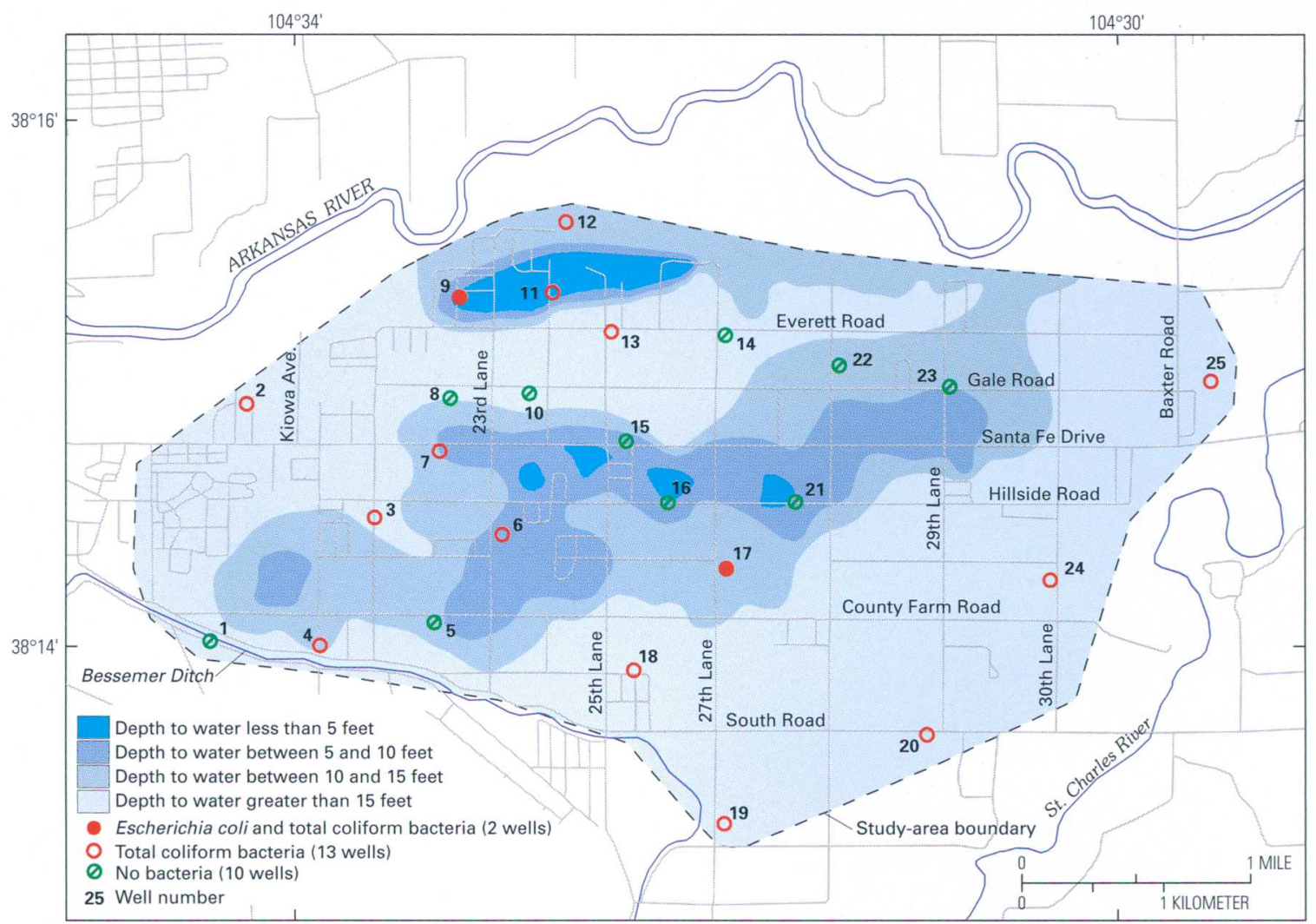

Figure 5. Detections of bacteria in samples obtained from wells on St. Charles Mesa during July and August 1997 


\section{REFERENCES}

Brendle, D.L., 1999, Extent of the high water table and watertable fluctuations, St. Charles Mesa, Colorado, April 1997 to October 1998: U.S. Geological Survey Fact Sheet 102-99, 4 p.

Canter, L.W., and Knox, R.C., 1985, Septic tank system effects on ground water quality: Chelsea, Mich., Lewis Publishers, $336 \mathrm{p}$.

Dumeyer, J.M., 1975, Hydrogeology of St. Charles Mesa, Pueblo County, Colorado: Colorado Geological Survey, Department of Natural Resources, map rèport, 1 p.

Edelmann, P.F., Scaplo, J.A., Colalancia, D.A., and Elson, B.B., 1991, Compilation of water-quality data for Pueblo Reser-. voir and the upper Arkansas River Basin, Colorado, 1985-87: U.S. Geological Survey Open-File. Report 91-506, 409 p. .

Greenberg, A.E., Trussell, R.R., and Clescers, L.S.,; eds., 1985, Standard methods for the examination of water and wastewater (16th ed.): Washington, D.C., American Public Health Association, '1,268 p.

Robertson, W.D., Sudicky, E.A., Cherry, J.A., Rappaport, R.A., and Shimp, R.J., 1989, Impact of a domestic septic system on an unconfined sand aquifer, in Kobus, H.E., and Kinzelbach, W., eds., Proceedings of the international symposium on contaminant transport in groundwater, Stuttgart, Federal Republic of Germany, April 4-6, 1989: v. 3, p. 105-112.

Scott, G.R., 1969, Geologic map of the southwest and southeast Pueblo quadrangles, Colorado: U.S. Geological Survey Miscellaneous Geologic Investigations Map I-597, scale $1: 24,000$.

Thurman, E.M., 1986; Organic geochemistry of natural waters: Dordrecht, The Netherlands, Martinus Nijhoff/Dr. Junk Publishers, 497 p.

U.S. Environmental Protection Agency, 1995, Drinking water regulations and health advisories: Washington D.C., Office of Water, $15 \mathrm{p}$.
Viraraghavan, T., and Warnock, R.G., 1976, Ground-water quality adjacent to a septic tank system: Journal of the American Water Works Association, v. 68, no. 11, part 1, p. 611-614.

Wilhelm, S.R., Schiff, S.L., and Cherry, J.A., 1994, Biogeochemical evolution of domestic waste water in septic systems-1. Conceptual model: Ground Water, v. 32, no. 6, p. 905-916.

\section{-D.L. Brendle}

Many thanks to the well owners on the St. Charles Mesa.

Information on technical reports and hydrologic data can be obtained from:

\section{U.S. Geological Survey, Water Resources Division 200 W. 8th Street, Suite 200 \\ Norwest Bank Building Pueblo, CO 81003 (719) 544-7155, ext. 103}

email: dlbrendle@usgs.gov 